\title{
Students with Visual Impairments' Access and Participation in the Science Curriculum: Views of Teachers of Students with Visual Impairments
}

\author{
Karen E. Koehler* \\ Shawnee State University
}

\author{
Tiffany A. Wild \\ The Ohio State University
}

\begin{abstract}
Science is a core curricular area of instruction for all students and the federal mandates of the Individuals with Disabilities Education Act (2004) and No Child Left Behind (2001) require that students with disabilities are educated in the least restrictive environment and have access to general education science content, based upon rigorous standards. While, most students with visual impairments are educated in the general science classroom, few studies have been done to determine whether appropriate accommodations and modifications are being made in those classrooms to meet the specialized needs of these students. A 35 question survey instrument was disseminated to teachers of the visually impaired through a Visual Impairments Listserve and Facebook group to help determine what pedagogical practices, accommodations, modifications, adaptive equipment and instructional practices are being used to educate students with visual impairments in the United States and Canada. This study helped inform how students with visual impairments are being educated in the science classroom.
\end{abstract}

*Corresponding Author, Karen E. Koehler (email address)

Submitted January 16, 2019

Accepted May 6, 2019

Published online July 24, 2019 
Vol. 22, No. 1 - 2019

Journal of Science Education for Students with Disabilities

\section{INTRODUCTION}

The Individuals with Disabilities Education Act of 1990 (IDEA, 1990) and its reauthorization Individuals with Disabilities Education Improvement Act of 2004 (IDEIA, 2004) mandate that students with disabilities have access to educational experiences in the least restrictive environment (LRE). The No Child Left Behind Act of 2001 (NCLB, 2002) requires that they have access to general education content taught by highly qualified instructors. Additionally, NCLB requires that students with disabilities be held to rigorous standards and participate in standardized testing based upon those standards.

Moreover, the Next Generation Science Standards (NGSS) advocate for excellence and equity for all students including those with disabilities (Achieve, 2013). The Next Generation Science Standards were developed to provide a consistent science education framework for ALL students based upon practices, core ideas and crosscutting concepts. (Achieve, 2013) and were subjected to a full review by the diversity and equity team (Miller \& Januszyk, 2014). The NGSS draw upon current research about how students learn science and attempt to reduce the disparities in student outcomes across diverse groups (Miller \& Januszyk, 2014). Appendix D of the NGSS, "All Standards, All Students" (NGSS Lead States, 2013) provides teachers with case studies demonstrating how the standards can be implemented in classrooms with diverse populations. At the heart of the case study addressing students with disabilities are the principles of Universal Design for Learning (CAST, 2012) and differentiated instruction. In Universal Design for Learning (UDL), barriers to learning are removed to improve and optimize teaching and learning for all people based on scientific insights into how humans learn. The use of Universal Design for Learning (UDL) frameworks provides multiple modes of access and engagement with content, as well as, multimodal means for student expression (CAST, 2012). Through the use of multimodal representations, students with disabilities can be supported in their understanding of complex science concepts and have options for demonstrating science understanding, aligning well with UDL (Taylor et al., 2017).

The framework of NGSS stresses the importance of teaching science through inquiry based methods which has been shown to be an effective instructional strategy for students with visual impairments (Koehler, 2017; Hilson, Hobson \& Wild, 2016; Wild, Hilson, \& Farrand, 2013; Wild, Hilson \& Hobson, 2013; Wild \& Trundle, 2010a; 2010b). In an inquiry-based classroom, students engage in the actual work of scientific investigation of the natural world through scientifically oriented questioning and discovery (Wild \& Koehler, 2017). Students with visual impairments can participate in inquiry based methods of exploration in a similar manner as their sighted peers, but require accommodations and access to modified equipment (Wild \& Koehler, 2017). For example, a student who is blind may need access to modified lab equipment such as a talking thermometer, braille metric ruler or a braille periodic table in order to be a full participant in a scientific investigation. While this equipment is readily available in the marketplace, general education teachers and administrators may not know of its existence. Further complicating the situation can be the lack of training for general educators 
on the use on both high tech and low tech equipment for students with visual impairments. Therefore, the role of the teacher of students with visual impairments, as a collaborator, becomes critical for ensuring access to the modified equipment and other accommodations that students with visual impairments require to be successful in today's science classroom.

Approximately 60,000 children, ages three through twenty-one, in the United States, have a documented visual impairment, which may affect their educational functioning (American Printing House, 2014). According to the U.S. Department of Education, National Center for Education Statistics (2017), approximately $90 \%$ of students with visual impairments receive instruction in the general education classroom for at least a portion of their school day. While many definitions of visual impairment exist, IDEA defines visual impairment as "an impairment in vision that, even with correction, adversely affects a child's educational performance. The term includes both partial sight and blindness" (IDEA, 2004).

Instruction in the general education science classroom typically relies on highly visual content and instructional practices that must be made accessible for students with visual impairments (Ross \& Robinson, 2000; Sahin \& Yorek, 2009; Koehler \& Wild, 2016; Wild \& Koehler, 2017). Students with visual impairments, educated in the general education science classroom, require accommodations in order to access this highly visual science content and often receive services from a Certified Teacher of the Visually Impaired (TVI), who can assist the content area teacher in making the necessary accommodations to the science curriculum. Little research exists that evaluates whether students with visual impairments are receiving the necessary accommodations to the curriculum in the science room and whether science content is truly made accessible for these students (Wild \& Paul, 2012).

This study expands upon a research study by Wild \& Paul (2012) that sought to examine the types of practices that were in use in general education science classrooms to make science accessible to students with visual impairments. It expands the previous study by examining specific science pedagogy, equipment, accommodations, modifications, and assistive technology used in the science classroom by students with visual impairments, as reported by TVIs. Additionally, it helps inform if the goals of the NCLB and IDEA legislation are being realized by students who are visually impaired. This descriptive study sought to answer the following research questions:

1. What pedagogical practices are in place to help students with visual impairments access the science curriculum in classrooms across the United States and Canada?

2. What accommodations and modifications are used to help these students access the curriculum in a science classroom?

Very little research exists that examines how students with visual impairments are being educated in the science classroom. Wild and Paul (2012) developed a 10 question survey instrument, distributed to teachers of students with visual impairments (TVIs), which gathered data about science content delivery. The questions were designed to gather general information about standards-based content delivery, inquiry-based instruction, laboratory experiments, physical and 
biological science participation, astronomy participation, pedagogy, assessment, length of time spent in general education, and support by the teacher of students with visual impairments. Their study found that a majority of students with visual impairments are being educated according to state science standards, in the general education science classroom, and are participating in experiments with their sighted peers. Additionally, $26 \%$ of the participants stated that science materials were adapted to meet the needs of students with visual impairments.

Much of the research on science instructional strategies for students who are visually impaired is related to making accommodations to existing science curricula and science materials, in order to provide access for those students (Jones, Minogue, Oppewal, Cook, Broadwell, 2006; Rule, 2011; Kumar, Ramasamy \& Stefanich, 2001). Rule (2011) reported on an accessible space camp at a specialized school for the blind that provided students with hands-on experiences and materials adapted for student's level of vision. Students attending the camp expressed very positive attitudes during the camp due to the access to these hands-on accessible materials, and expressed less positive attitudes about their experiences in the general education classroom. There is little research to show if these accessible instructional strategies are actually being used in the science classrooms in which students with visual impairments are being educated.

Kahn and Lewis (2014) found that teachers do not feel equipped to adequately teach students with visual impairments in the general education science classroom and are receiving very little training, prior to on the job training. The role of a teacher of the visually impaired is an important one that helps to ensure that general education teachers understand the unique needs of these students.

This study sought to understand what science education for students with visual impairments looks like in the classroom, from the unique perspective of TVIs. From this vantage point, this study attempted to gauge common science pedagogy, instructional strategies, accommodations and modifications in use for students with visual impairments across the United States and Canada.

\section{METHOD}

\section{Participants}

The participants in this study included teaching members of the Association for the Education of the Blind and Visually Impaired (AER) and members of the Facebook group Teachers of the Blind and Visually Impaired/O\&M Specialists. Convenience sampling was used to access the participants for this study because the target population is teachers of the visually impaired, many of whom are members of AER and subscribe to the Facebook group. The participants were solicited to participate in this study through email solicitation via the AER listserve and through the VI Facebook group. Solicitation of these members provided direct feedback on what was happening in science classrooms for students with visual impairments, as TVIs are a direct link to these students, have expert knowledge on instructional practices for students with visual impairments, and potentially have experience working with these students in the science classroom. 


\section{Data Collection}

The purpose of this study was to examine how students with visual impairments access the science classroom, what instruments they use in the science classroom, what modifications and accommodations are being used in the science classroom, and what assistive technology is being used. An online survey was disseminated to participants through Qualtrics, an online survey system. The survey was password protected, the password was only known to the researchers in the study, and all results were anonymous. An initial solicitation email and announcement was sent to prospective participants in both the listserve and Facebook group asking for participation in the survey. A follow-up solicitation was given 2 weeks after the initial solicitation.

\section{Instrument}

The survey, created by the researchers, was used to collect data for this research study. The instrument contained both demographic questions along with questions about pedagogy and instruments used in the science classroom. Questions were a combination of open-ended, yes/no, and Likert (always, often, rarely, never, n/a, or don't know). Sample questions include:

Please describe some of the accommodations that you make to include students with visual impairments.

\section{a. [text box]}

If your students with visual impairments are not being fully included, please describe modifications made to the activity or alternative activities in which the student participated.

\section{b. [text box]}

A total of 35 questions was asked, with some questions having a set of subquestions attached. The survey instrument was kept relatively short to prevent instrument decay. The instrument was designed by the researchers, who are both certified teachers of the visually impaired and certified science teachers, in an attempt to increase validity of the instrument by helping to ensure that the content related evidence is valid.

\section{Data Analysis}

Descriptive statistical analysis was used to analyze the data. All qualitative data was analyzed by observing themes and patterns. The emerging themes were assigned a number and tallied for a numeric representation of occurrence. Percentages of response rates and patterns was reported. Reliability was improved by having each researcher code and score the data separately and discuss any discrepancies until full agreement was reached. It was not possible to contact the respondents for a follow-up survey due to the constraints of the university approvedIRB. Some quotes of participants will be used in order to substantiate the data.This data analysis plan is appropriate given the nature of this study and the categorical data being collected.

\section{Human Subjects}

The risks of participating in the study were minimal. No identifiable data was collected, and the researchers do not have access to the names of the participants in the list serve. The surveys are password protected and can only be accessed by the researchers. The surveys will remain in the system 
Vol. 22, No. 1 - 2019

Journal of Science Education for Students with Disabilities

for 5 years and then destroyed. This survey research was voluntary and participants may withdraw at any time without penalties or loss of benefits.

\section{RESULTS}

A total of 51 participants responded to the survey. $86 \%$ of the respondents were female and $14 \%$ of the respondents were male. The race and ethnicity of the respondents is as follows: $85 \%$ white, $2 \%$ latino/a, $2 \%$ bi/multiracial, $2 \%$ other, $7 \%$ refuser to answer. $90 \%$ of the respondents were not visually impaired; however, $10 \%$ did have a visual impairment. $47 \%$ of the respondents had been teaching more than 15 years and 53\% had less than 15 years of teaching experience. The participants represented 18 U.S. states and 1 Canadian province. 52\% of the respondents serve students with visual impairments, 25\% serve students with multiple disabilities, $11 \%$ serve those who are deafblind and $11 \%$ responded that they serve "other". In responding to the question "what age groups do you serve", the following results were found: $13 \%$ preschool, $23 \%$ elementary, $20 \%$ middle school, $36 \%$ high school and 8\% post high school. 74\% of respondents work in a public school, 14\% work in a specialized school, $5 \%$ in a charter school and 7\% responded "other", which included social service agency, non-profit agency and consultant. $82 \%$ of respondents identified themselves as itinerant teachers, $7 \%$ as residential classroom teachers, $5 \%$ as resource classroom teachers and $5 \%$ as other, which included consultants.

\section{Access to the General Education Classroom}

Previous studies found the majority of students with visual impairments receive their science instruction in the general education classroom. When asked "In what setting do you spend the majority of your time related to science education for your students," $45 \%$ of the teachers responded general education classroom, $37 \%$ stated one on one with students, 3\% said science classroom in a residential setting, 3\% stated resource room and 15 responded "other", which included consultation and self-contained room. Seventy percent $(70 \%)$ of respondents stated that at least $75 \%$ of their students received instruction in the general education science classroom and many responded that $100 \%$ of their students were being educated in the science classroom. Likewise, eighty percent of respondents said that at least $75 \%$ or more of their students had access to the science content based upon the science curriculum standards of their state or province and many responded that $100 \%$ of their students were educated based upon those standards. One respondent, however, commented that the students who were braille readers did not have access to braille textbooks.

Responses to the question "what percentage of your high school age students take advanced science courses such as Chemistry, Physics, Advanced Biology, etc.?", the responses were much more varied. Only $17 \%$ of the respondents stated that more than $75 \%$ of their students took advanced science courses and $23 \%$ said that none of their students with visual impairments took advanced science classes. Similar results were found when respondents were asked about advanced placement science classes 
- over half of the respondents $(58 \%)$ said that none of their students take advanced placement science classes and only $25 \%$ stated that a small minority of their students have taken these classes. According to the survey, $54 \%$ of the respondents do not attend science classes with their students with visual impairments and $31 \%$ do attend with their students.

\section{Accommodations in the Science Classroom}

Ninety-four (94) percent of the respondents stated that it was at least sometimes their responsibility to make accommodations in the science classroom for their students with visual impairments. The survey participants were also asked to describe some of the accommodations that they make to include students with visual impairments. The data was coded and the types of accommodations fell into certain categories as shown in the Table 1 below.

The most common accommodations included: making content accessible through providing and producing tactile materials, including models and images. The respondents also commonly produced accessible media, including braille and large print. The respondents stated that they were responsible

\begin{tabular}{|c|c|}
\hline Code & $\begin{array}{l}\text { Number of } \\
\text { Participant } \\
\text { Responses }\end{array}$ \\
\hline Tactile models, images, 3D models & 17 \\
\hline Improving contrast of images & 1 \\
\hline Discussions & 1 \\
\hline $\begin{array}{l}\text { Promote self-determination - student asking for } \\
\text { needs }\end{array}$ & 3 \\
\hline Media production - braille, large print & 8 \\
\hline Assistive technology - including magnification & 8 \\
\hline Accessible lab materials - provide to students & 7 \\
\hline $\begin{array}{l}\text { Accommodations - verbal descriptions, } \\
\text { extended time, enlarged materials }\end{array}$ & 12 \\
\hline Pre teach skills/concepts & 3 \\
\hline $\begin{array}{l}\text { Teach other students how to work with individuals } \\
\text { with visual impairments }\end{array}$ & 1 \\
\hline
\end{tabular}

Table 1: Accommodations for students with visual impairments 
for providing a wide variety of assistive technology, including various magnification devices and making lab materials accessible to students with visual impairments. Finally, many of the respondents reported that they commonly accommodate the students through verbal descriptions, enlarging materials and allow for extended time. Some of the less common accommodations included: pre teaching skills and concepts to students and working with students to improve their self-determination when asking for assistance from the general education teacher. Respondents also help reinforce science lessons, work to improve concept development and act as a coteacher in the science classroom. More than $50 \%$ also said that it was sometimes or often their responsibility to teach science concepts to students with visual impairments.

In addition to making the accommodations in the science classroom, many described the ways that they collaborate with the general education teacher in the classroom. The majority of respondents spoke about daily or weekly communication with the general education science teacher as a method of collaboration, either via email or in person. Much of the collaboration centered on discussions related to making the content accessible for students with visual impairments. Thirty (30) percent of respondents spoke of either producing braille, tactile graphics and tactile materials for students or working with the general education teacher to make the content accessible. A few of the respondents mentioned that they collaborate to pre teach vocabulary and help with science concept development. It is clear that much of the collaboration with the general education teacher revolves around accommodations and mirrors the respondents' descriptions of those accommodations in earlier survey questions.

\section{Inclusion in the Science Classroom}

Inclusion in the science room for students with visual impairments is critical to their success and this research study sought to find out if students were being included and in which activities, in particular, they were being fully included. A number of survey questions related directly to inclusion of students with visual impairments in the general education science classroom. Given a list of activities 10 common activities/experiments conducted in the science classroom, participants were asked to rate the level of inclusion as: always, often, rarely, never or not applicable. Table 2, shown below, lists each activity and the level of inclusion as rated by the study participants.

According to the results of this study, students with visual impairments are always included in activities related to physics (57\%) and astronomy (59\%) at relatively high levels. However, they are not always included at relatively high levels in activities related to microscopes (28\%), dissections (34\%) and those involving chemical reactions (34\%). Likewise, the respondents stated that students with visual impairments are rarely involved in activities with microscopes was quite high at $31 \%$.

Survey participants were also asked "how often does the science teacher express concern over the danger of a student with visual impairments participating in a lab experiment". Based upon the responses by the teachers of the visually impaired, the majority rarely $(44 \%)$ or never $(15 \%)$ heard the science teacher expressing concern 


\begin{tabular}{llllll}
\hline Activity/Experiment & Always & Often & Rarely & Never & N/A \\
\hline $\begin{array}{l}\text { Experiments involving chemical } \\
\text { reactions }\end{array}$ & $34 \%$ & $24 \%$ & $14 \%$ & $7 \%$ & $21 \%$ \\
Dissections & $34 \%$ & $10 \%$ & $14 \%$ & $3 \%$ & $38 \%$ \\
Microscope activities & $28 \%$ & $14 \%$ & $31 \%$ & $7 \%$ & $21 \%$ \\
$\begin{array}{l}\text { Experiments involving pH } \\
\text { Experiments involving light }\end{array}$ & $34 \%$ & $34 \%$ & $7 \%$ & $0 \%$ & $24 \%$ \\
$\begin{array}{l}\text { Investigations with electricity } \\
\text { Contour mapping }\end{array}$ & $39 \%$ & $32 \%$ & $7 \%$ & $4 \%$ & $18 \%$ \\
$\begin{array}{l}\text { Activities involving astronomy } \\
\text { such as moon phases, eclipses, }\end{array}$ & $43 \%$ & $25 \%$ & $7 \%$ & $4 \%$ & $21 \%$ \\
seasons, stars, etc. & $59 \%$ & $28 \%$ & $0 \%$ & $3 \%$ & $10 \%$ \\
$\begin{array}{l}\text { Physics experiments: forces and } \\
\text { motion, etc. }\end{array}$ & $57 \%$ & $25 \%$ & $0 \%$ & $0 \%$ & $18 \%$ \\
$\begin{array}{l}\text { Engineering: building of new } \\
\text { equipment }\end{array}$ & $41 \%$ & $24 \%$ & $0 \%$ & $7 \%$ & $28 \%$ \\
\hline
\end{tabular}

\section{Table 2: Level of Inclusion in Science Activities}

related to concerns about the danger of students with visual impairments participating in lab experiments. The minority of the teachers of the visually impaired often $(30 \%)$ or always $(11 \%)$ heard the science teacher expressing concern.

A follow-up question asked "if your students with visual impairments are not being fully included, please describe modifications made to the activity or alternative activities in which the student participated. Responses to this question varied but were coded according to the following major themes as shown in Table 3.

The most common responses to this question centered on giving the student an alternate activity or using modifications and accommodations, such as modifying equipment, using tactile models or providing verbal descriptions of visual materials.
Computer simulations are becoming more commonplace in the science classroom as an instructional tool. Because of their increasing popularity, the researchers wished to find out whether these simulations were being made accessible for students with visual impairments. Participants were asked "how often are these computer simulations made accessible to the students with visual impairments." Thirty-nine percent (39\%) stated that they are always made accessible and twenty-two percent $(22 \%)$ said that they were often made accessible. However, $30 \%$ of the respondents said that the simulations were rarely made accessible and a small percentage (9\%) said they were never made accessible to the students with visual impairments. 
Vol. 22, No. 1 - 2019

Journal of Science Education for Students with Disabilities

\begin{tabular}{|c|c|c|}
\hline Code & Description & Number of respondents \\
\hline $\begin{array}{l}\text { MODIFIED } \\
\text { EQUIPMENT }\end{array}$ & $\begin{array}{l}\text { Using or producing } \\
\text { modifications to } \\
\text { equipment }\end{array}$ & 3 \\
\hline TACTILE & Use of tactile models & 4 \\
\hline DESCRIPTION & $\begin{array}{l}\text { Verbal description of } \\
\text { visuals or materials }\end{array}$ & 4 \\
\hline EXEMPTION & $\begin{array}{l}\text { Exempts student from } \\
\text { activity }\end{array}$ & 2 \\
\hline GEN ED & $\begin{array}{l}\text { General education } \\
\text { teacher incorrectly } \\
\text { makes own } \\
\text { modifications }\end{array}$ & 1 \\
\hline GROUP RECORDER & $\begin{array}{l}\text { Student with visual } \\
\text { impairment acts as a } \\
\text { recorder for the group }\end{array}$ & 2 \\
\hline PEER & $\begin{array}{l}\text { Peer assistant helps } \\
\text { student with visual } \\
\text { impairments complete } \\
\text { activity or describes } \\
\text { activity }\end{array}$ & 2 \\
\hline ALTERNATIVE & $\begin{array}{l}\text { Alternate activity } \\
\text { assigned to student with } \\
\text { VI }\end{array}$ & 3 \\
\hline TECH & $\begin{array}{l}\text { Use of assistive } \\
\text { technology }\end{array}$ & 2 \\
\hline VIDEO & Use of videos & 1 \\
\hline MODEL & Direct modeling by TVI & 1 \\
\hline SUPPORT & $\begin{array}{l}\text { TVI supports teacher in } \\
\text { the classroom }\end{array}$ & 1 \\
\hline MODIFY & $\begin{array}{l}\text { Modifications - did not } \\
\text { specify modification } \\
\text { techniques }\end{array}$ & 2 \\
\hline
\end{tabular}

Table 3: Methods of Inclusion 


\section{Access to Equipment and Materials}

A wide variety of accessible laboratory and science equipment and materials are available for students with visual impairments in the common marketplace and through organizations such as the American Printing House for the Blind. Some of these materials can be purchased using federal quota funds, available to students who meet the federal guidelines for having a visual impairment and who are registered with the American Printing House for the Blind. The researchers were interested in determining how often students have access to these important accessible materials and equipment in their science classroom. The respondents were asked to respond yes or no as to whether students had access to a list of 11 available accessible items in their science classroom and the results are shown in Table 4 below.

Upon examining this data, one can observe that not all materials are equally available to students with visual impairments in the science classrooms, as reported by the teachers of the visually impaired in this study. Some materials, such as braille and large print measuring tools, talking scientific calculators and modified lab equipment are available to students more often than talking balances and electronic lab equipment modified specifically for students with visual impairments - talking LabQuest $(\mathrm{C}$ and SciVoice Lab Solutions $\mathbb{C}$.

\section{DISCUSSION}

This study supports previous research conducted by Wild \& Paul (2012). The majority of students with visual impairments spend their instructional time in science within the general education classroom. While in those classrooms, students with visual impairments are receiving standards-based education. However, it is important to note that the teachers of students with visual impairments reported that they do not spend a proportionate amount of time in the general education classroom as the students they support. Therefore, it is important that general education teachers understand how to support the learning and make accommodations for students with visual impairments.

While the students are spending the majority of time in general education, only $17 \%$ of the teachers responded that the majority of their students took advanced science courses. Furthermore, over half of the respondents said that none of their students take advanced placement science classes and only $25 \%$ stated that a small minority of their students have taken these classes. Unfortunately, without those higher-level science courses, students with visual impairments may not be prepared for university or college level courses in science or prepared for technical careers that rely upon skills in science further hindering employability.

Ninety-four percent of the respondents indicated that it was at least sometimes their responsibility to make accommodations for their students with visual impairments. The most common accommodations were preparing tactile images and providing accommodations such as verbal descriptions, extended time and large print. One of the least reported activities was that of teaching other students how to work with students with visual impairments. By teaching others to work with students with visual impairments, educational opportunities for students with visual impairments 
Vol. 22, No. 1 - 2019

Journal of Science Education for Students with Disabilities

\begin{tabular}{|c|c|c|}
\hline \multirow[t]{2}{*}{$\begin{array}{l}\text { Accessible } \\
\text { Equipment/Materials }\end{array}$} & \multicolumn{2}{|c|}{$\begin{array}{l}\text { Student Access in Science Classroom } \\
\text { ( } \% \text { of Respondents) }\end{array}$} \\
\hline & Yes & No \\
\hline Talking scale & 48 & 52 \\
\hline Talking balance & 17 & 83 \\
\hline Talking Labquest $\mathbb{C}$ & 9 & 91 \\
\hline SciVoice Lab Solutions(C) & 17 & 83 \\
\hline Color identifier & 59 & 41 \\
\hline Liquid level indicator & 55 & 45 \\
\hline $\begin{array}{l}\text { Talking scientific } \\
\text { calculator }\end{array}$ & 88 & 12 \\
\hline $\begin{array}{l}\text { Modified lab equip } \\
\text { (beakers, graduated } \\
\text { cylinders, etc.) }\end{array}$ & 70 & 30 \\
\hline Braille/large print rulers & 96 & 4 \\
\hline $\begin{array}{l}\text { Braille/large print } \\
\text { measuring tape }\end{array}$ & 80 & 20 \\
\hline $\begin{array}{l}\text { Azer's Accessible Periodic } \\
\text { Table(C) }\end{array}$ & 60 & 40 \\
\hline
\end{tabular}

Table 4: Student access to accessible equipment and materials

could be increased by being fully included in laboratory activities, demonstrations, and presentations.

Laboratory participation of students with visual impairments had a low rate of inclusion of students with visual impairments. Experiments with chemical reactions, dissections, electricity, $\mathrm{pH}$, and microscope activities were all reported as have low rates of participation while physics and engineering experiences were reported as high levels of participation. Kahn and Lewis (2014) reported that science teachers felt the least prepared to teach students with visual impairments and orthopedic impairments and were not instructed on safety concerns and modifying lessons for students with disabilities. This study reflects that point. Teacher preparation programs need to do a better job of teaching pre-service teachers how to fully include ALL of their students 
in the classroom. Unfortunately, when the students with visual impairments were not included in a science activity, they were given an alternate activity or a modified activity.

Further inhibiting participation if the science classroom was that of access to materials and equipment. The amount of access varied greatly. Basic equipment such as braille and large print measuring tools and talking scientific tools were available while sophisticated laboratory equipment developed specifically for students with visual impairments such as the - Talking LabQuest $(C$ and SciVoice Lab Solutions $\subset$ was not. The Talking Lab Quest (C) provides students with visual impairments the opportunity to have real-time data readings available in an audible format. Sensors can be used to provide access to biology, chemistry and physics experiments (www. gwmicro.com) SciVoice(C) adds additional functionality to the LabQuest $(C$ device in the science classroom. The noted lack of available equipment could be contributing to the overall lack of student participation in higher-level science classrooms and laboratory experiences.

What is unclear from this data is if there was a lack of access or lack of training and knowledge about the various equipment made available to the field of visual impairment education. The researchers only provided an extensive list of equipment. Researchers provided no explanation in the survey on these devices or their use. Bausch and Hasselbring (2004) note that there are barriers that exist to proper implementation of assistive technology in the classroom. One such barrier is due to the number of devices available to students with disabilities. With all the devices, it is hard to keep up on student need. There is also a lack of training in use and integration of assistive technology devices, as well as a shortage of personnel who receive training to support the use of the device in the classroom. Further compounding this problem is a lack of teacher training programs that require special education pre-service teachers to receive training in assistive technology. Less than $25 \%$ of master's degree programs in special education and one-third of undergraduate special education licensure programs provide instruction in assistive technology (Judge \& Simms, 2009).

\section{Limitations}

The survey instrument is a limitation of this study. Even though the survey questions were developed by the two researchers, who are experts in the area of teaching science to students with visual impairments, the questions were not vetted by others. Additionally, the survey instrument is not a standardized survey instrument, but it was based on a previous survey instrument used by Wild and Paul (2012).

Further limiting this study was that of the participants. This research was conducted using convenience sampling from members of the AER listserve and VI Facebook group; therefore, the findings may only represent the opinions of this group, rather than the entire population of teachers of the visually impaired. The survey was designed to be anonymous thus, the researchers were unable to follow up to conduct further interviews with respondents in order to check for reliability of the data collected. Additionally, the inability to follow-up with respondents did not allow researchers to explain any educational terminology that may be 
unfamiliar to research participants; which could have had an impact on results. Finally, while each researcher coded the data separately and compared the results, a calculation of interrater reliability was not completed.

\section{CONCLUSION}

While this study showed that students with visual impairments are being included, a majority of the time in general education science classrooms, what was disconcerting is the lack of participation levels in those experiences. It was reported by the respondents that their students with visual impairments did not get to fully participate in dissection experiences, higher level science classes, or chemistry experiences. All of these experiences could easily be accessible to students with visual impairments with the equipment that was reported as not being available and proper teacher training which was reported by Kahn and Lewis (2014) as not happening.

While more research needs to be conducted on how students with visual impairments experience science education, this research does provide more detailed information than previously reported by Wild \& Paul (2012). Future research should continue to determine, using a wider frame of participants, how students with visual impairments are accessing the science education. Future research should examine why students are not participating fully in the science classroom and examine barriers to full inclusion.

\section{REFERENCES}

Achieve. (2013). Next generation science standards: Achieve, Inc. on behalf of the twenty-six states and partners that collaborated on the NGSS. Retrieved from http://www.nextgenscience.org/

American Printing House for the Blind Annual Report (2014). Distribution of Eligible Students Based on the Federal Quota Census of January 7, 2013 (Fiscal Year 2014). Retrieved from The American Printing House website: http:// www.aph.org/federal-quota/dist14.html

Bausch, M. \& Hasselbring, T. (2004). Assistive technology: Are the necessary skills and knowledge being developed at the preservice and inservice levels? Teacher Education and Special Education, 27(2), 97-104.

CAST, Inc. (2012). National Center on Universal Design for Learning. Retrieved from http://www.udlcenter.org/

Hilson, M., Hobson, S., \& Wild, T. (2016). Conceptual understandings of students with visual impairments about biodiversity across ecosystems. Journal of Blindness Innovation and Research, 6(2). Retrieved from https://nfb.org/ images/nfb/publications/jbir/jbir16/ jbir060204.html. doi: http:/dx.doi. org/10.5241/6-102

Individuals with Disabilities Education Act of 1990, Pub.L. 101-476, 104 Stat. 1142 (1990)..

Individuals with Disabilities Education 
Improvement Act of 2004, Pub. L. No. 108-446, 118 Stat. 2647 (2004).

Jones, M. G., Minogue, J., Oppewal, T., Cook, M. P., \& Broadwell, B. (2006).

Visualizing without vision as the microscale: Students with visual impairments explore cells with touch. Journal of Science Education \& Technology, 15(5/6), 345-351.

Judge, S. \& Simms, K. (2009). Assistive technology training at the pre-service level: A national snapshot of teacher preparation programs. Teacher Education and Special Education, 32(1), 33- 44.

Kahn, S., \& Lewis, A. R. (December 01, 2014). Survey on teaching science to k-12 students with disabilities: teacher preparedness and attitudes. Journal of Science Teacher Education: the Official Journal of the Association for Science Teacher Education, 25(8), 885-910.

Koehler, K. Examining the Conceptual Understandings of Geoscience Concepts of Students with Visual Impairments: Implications of 3-D Printing (Electronic Thesis or Dissertation). Retrieved from https://etd.ohiolink.edu/

Koehler, K. \& Wild. T. (April, 2016). Participation in the science curriculum for students with visual impairments. Presentation at the Council for Exceptional Children Conference, St. Louis, Missouri.

Kumar, D., Ramasamy, R., and Stefanich, G., 2001, Science for students with visual impairments: Teaching suggestions and policy implications for secondary educators: Electronic Journal of Science Education, 5(3), Retrieved September 20, 2009,from http://unr.edu/homepage/ crowther/ejse/kumar2etal.html

Miller, E. \& Januszyk, R. (2014). The ngss case studies: All standards, all students. Science and Children, 51(5), 10-13.

NGSS Lead States. 2013. Appendix D "All Standards, All Students": Making the Next Generation Science Standards accessible to all students. In Next Generation Science Standards: For states, by states, volume 2: Appendices ed. NGSS Lead States, 25-39. Washington, DC: National Academies Press. www.nextgenscience.org/nextgenerationscience-standards.

No Child Left Behind Act of 2001, 20 U.S.C. 6301 et seq. (2006).

Ross, D. \& Robinson, M. (2000). Social Studies and Science. In Koenig, A. \& Holbrook, M. (Eds.). Foundations of Education Volume II: Instructional Strategies for Teaching Children and Youths with Visual Impairments (2nd ed.). New York: AFB Press.

Rule, A. (2011). Tactile earth and space science materials for students with visual impairments: contours, craters, asteroids and features of mars. Journal of Geoscience Education, 59, 205-218.

Sahin, M. \& Yorek, N. (2009). Teaching science to visually impaired students: A small-scale qualitative study. US-China Education Review, 6(4), 19-26. 
Taylor, J. C., Koehler, K, Rizzo, K., \& Hwang, J. (2017). The rise of measurement: Assessing science and the implications for students with special needs. In Koomen, M., Kahn, S., Atchison, C., and Wild, T. (Eds.). Toward inclusion of all learners through science teacher education, The Netherlands: Brill Publishers.

U.S. Department of Education (2011). 31st annual report to congress on the implementation of the Individuals with Disabilities Education Act (IDEA), 2009. Retrieved from: http://www2.ed.gov/ about/reports/annual/osep/2009/parts-b-c/ index.html

U.S. Department of Education, National Center for Education Statistics. (2017). Digest of Education Statistics, 2016 (NCES 2017-094),

Wild, T., Hilson, M. \& Farrand, K. (2013). Conceptual understandings of geological concepts by students with visual impairments. Journal of Geoscience Education, 61, 222-230.

Wild, T., Hilson, M., Hobson, S. (2013). Conceptual understandings of sound by elementary students with visual impairments. Journal of Visual Impairment and Blindness, 107(2), 107-116.

Wild, T. \& Koehler, K. (2017). Science education. In Holbrook, C., KameiHannan, C, \& McCarthy, T. (Eds.) Foundations of education volume II (2nd ed.). New York: AFB Press.
Wild, T. \& Paul, P. (2012). Perceptions of science educational practices for students with visual impairments. Insight: Research and Practice in Visual Impairment and Blindness, 5(2), 93-99.

Wild, T. \& Trundle, K. (April, 2010a). Talking turkey: Teaching about america's greatest conservation story with children with visual impairments. Journal of Visual Impairment \& Blindness, 104(4), 198-201.

Wild, T \& Trundle, K. (February, 2010b). Conceptual understandings of seasonal change by middle school students with visual impairments. Journal of Visual Impairment \& Blindness, 104(2), 107-108. 
Students with Visual Impairments' Access and Participation in the Science Curriculum 